\title{
A Multiple-Code Simulation Study of the Long-term EDZ Evolution of Geological Nuclear Waste Repositories
}

Jonny Rutqvist ${ }^{1 *}$, Ann Bäckström ${ }^{2}$, Masakazu Chijimatsu ${ }^{3}$, Xia-Ting Feng ${ }^{4}$, PengZhi Pan ${ }^{4}$, John Hudson ${ }^{5}$, Lanru Jing ${ }^{2}$, Akira Kobayashi ${ }^{6}$, Tomofumi Koyama ${ }^{2}$, Hee-Suk Lee ${ }^{7}$, Xiao-Hua Huang ${ }^{4}$, Mikael Rinne ${ }^{7}$, Baotang Shen ${ }^{7}$

${ }^{1}$ Earth Sciences Division, Lawrence Berkeley National Laboratory, MS 90-1116, Berkeley, CA 94720 , USA

${ }^{2}$ Royal Institute of Technology, Stockholm, Sweden

${ }^{3}$ Hazama Corporation, Tokyo, Japan

${ }^{4}$ State Key Laboratory of Geomechanics and Geotechnical Engineering, Institute of Rock and Soil Mechanics, Chinese Academy of Sciences, Wuhan, China

${ }^{5}$ Imperial College and Rock Engineering Consultants, UK

${ }^{6}$ Kyoto University, Kyoto, Japan

${ }^{7}$ FRACOM Ltd, Australia, Finland, Korea

* Corresponding author. Tel.: +1-510-486-5432, fax.: +1-510-486-5432

E-mail address: Jrutqvist@lbl.gov (J. Rutqvist)

\section{Prepared for publication in Environmental Geology}

DECOVALEX-THMC Special Issue 


\section{Abstract}

This simulation study shows how widely different model approaches can be adapted to model the evolution of the excavation disturbed zone (EDZ) around a heated nuclear waste emplacement drift in fractured rock. The study includes modeling of coupled thermal-hydrological-mechanical (THM) processes, with simplified consideration of chemical coupling in terms of time-dependent strength degradation or subcritical crack growth. The different model approaches applied in this study include boundary element, finite element, finite difference, particle mechanics, and elastoplastic cellular automata methods. The simulation results indicate that thermally induced differential stresses near the top of the emplacement drift may cause progressive failure and permeability changes during the first 100 years (i.e., after emplacement and drift closure). Moreover, the results indicate that time-dependent mechanical changes may play only a small role during the first 100 years of increasing temperature and thermal stress, whereas such timedependency is insignificant after peak temperature, because decreasing thermal stress.

\section{Keywords:}

coupled THM, nuclear waste repository, excavation disturbed zone, damage, permeability. 


\section{Introduction}

The excavation disturbed zone (EDZ) around tunnels, has been studied since the early 1980s, when the effects of the EDZ on hydraulic behavior around tunnels was first realized at the Stripa Mine experiments in Sweden (Witherspoon 2000). During the past 25 years, a large fraction of EDZ studies have involved measurements of mechanical responses during mine-by experiments, seismic velocity evaluation of excavation damaged zones due to blasting, as well as in situ tests to quantify permeability changes around underground openings. Such tests include in situ tests at the Äspö Hard Rock Laboratory, Sweden (Emsley et al. 1997), at the Kamaishi and Tono Mines in Japan (Sugihara et al. 1999), at the Underground Research Laboratory in Manitoba, Canada (Bäckblom and Martin 1999).

Findings of EDZ in situ experiments have led to a few general observations regarding EDZs and excavation-induced-permeability changes (Bäckblom and Martin 1999; Rutqvist and Stephansson 2003; Tsang et al. 2005). The EDZ includes a damaged zone of induced rock failure and fracturing, stemming from excavation processes; an unsaturated zone; a zone with altered stress distribution around the tunnels; and a zone of reduced fluid pressure (Fig. 1). In the case of excavation-induced damage, high transmissivity will probably develop close to the opening. For mechanical excavation (using no blasting) in a moderate-stress environment, the damage zone may be limited to a few centimeters thickness, where a limited change in porosity and permeability may take place. When drill-and-blast is used for excavation, the damage zone is more extensive, and therefore increased permeability is likely, especially in the tunnel floor, where the permeability can increase by two to three orders of magnitude. 
Concerning repository concepts involving emplacements in bentonite-backfilled excavations in deep fully saturated rock, the EDZ is studied because it could provide a fast flow path for radionuclide transport along nuclear waste emplacement drifts connecting to highly permeable rock fractures and fracture zones. In such a system, EDZ may affect the near-field function of the engineered barrier system, e.g., the bentonite buffer surrounding the waste canisters, which may be impacted by the formation of damaged rock in the EDZ. Moreover, in the recent Swedish SRCan project, it was concluded that the spalling around the deposition holes could have considerable impact on the flow rate and radionuclide mass transfer around nuclear waste deposition holes (SKB 2006). Water will be drawn into the damaged zone from fractures intersecting the deposition hole, leading to an increased mass transfer between the buffer and the rock. For the pessimistic case of a very high hydraulic conductivity in the spalled zone, it was estimated that thermal spalling in the EDZ would increase the dose that could be released from the geosphere by almost an order of magnitude (SKB 2006). It is therefore important to study how the EDZ evolves, both during excavation and during the thermal period after waste emplacement, since changes in EDZ permeability of the EDZ occurring during the thermal-stress peak may be irreversible, meaning that they would remain over the entire compliance period.

This paper presents an international, multiple-code simulation study of the evolution of the EDZ around a hypothetical nuclear waste repository in fractured rock. The study conducted as part of the DECOVALEX-THMC project (2004-2007), Task B, related to characterization and modeling of EDZ, including evaluation of coupled thermal, hydrological, mechanical, and chemical (THMC) processes (Hudson et al. 2008). Five research teams studied this simulation problem, 
using a wide range of numerical methods, including boundary element, finite element, finite difference, particle mechanics, and cellular automata (Table 1). A summary of the entire Task B and a detailed presentation of the application of the new cellular automata approach are provided in accompanying papers by Hudson et al. (2008) and Pan et al. (2008), respectively. The detailed definition of this simulation problem and the complete set of results are reported in Rutqvist et al. (2008a). In this paper, we briefly present the problem definition, the applied modeling approaches, and selected simulation results related to the evolution of the EDZ. These include the evolution of stress, failure, and permeability, and an assessment of time-dependent effects during the 100,000-year simulation time. We conclude with a discussion of the simulation results, leading to an assessment of how the different modeling approaches can be used to analyze different aspects of EDZ evolution at different scales.

\section{Model Setup}

The simulations were conducted for two model domains close to an emplacement drift (Fig. 2): (1) a near-field model domain, and (2) a wall-block model domain (Rutqvist et al. 2008a). The near-field model domain extended a few meters into the rock from the drift wall and allowed analysis of both the evolution and extent of the EDZ. The smaller-sized wall-block model domain was used for detailed analysis of coupled processes within the EDZ. Various degrees of fracturing were considered, as shown in Fig. $2 b$ and c. For the near-field model domain, the fracture pattern was derived from detailed fracture mappings near a drift at the Äspö Hard Rock Laboratory, Sweden. The relatively small model domains adopted for this simulation problem 
allowed a very fine model discretization, enabling detailed studies of rock failure processes in the EDZ.

The aim was to simulate, as closely as possible, the THM impact on the EDZ over a 100,000year repository lifetime. Because the near-field and the wall-block model domains in Fig. 2 represent only a small part of the repository system, results from a separate large-scale analysis were used to derive time-dependent boundary and interior conditions to be imposed in the nearfield and wall-block models (Fig. 3). The large-scale analysis included complete THM analysis of rock and bentonite buffer, to calculate the evolution of temperature, fluid pressure, bentonite saturation and swelling, and thermal stresses (see Rutqvist et al. 2008b).

The simulation problem was divided into several modeling stages, starting with a well-defined linear thermal-hydro-elastic analysis, and then successively adding components of complexity, including nonlinear and time-dependent material behavior and fractures. The material properties for the first stage consisted of well-defined linear elastic properties of intact granite (Table 1). The model results of the different research teams for the first linear thermal-hydro-elastic model stage were compared in detail to ensure that the time-dependent boundary and interior conditions had been correctly implemented before including more complex, nonlinear, and time-dependent processes (Rutqvist et al. 2008a). Properties for the following modeling stages, including properties for evaluating mechanical failure, changes in permeability, and potential timedependent effects, were based on data from the Äspö Hard Rock Laboratory and from literature data on crystalline rocks. 


\section{Approaches for Modeling of EDZ Evolution}

Each research team applied their numerical simulators and associated modeling approaches to both the wall-block and near-field model domains to analyze processes relevant to the evolution of the EDZ. Different approaches were used regarding (1) numerical methods and discretization of the problem, (2) assessment of the evolution of damage and permeability and (3) assessment of time-dependent effects. The main approaches for the near-field model are summarized in Table 3, with reference to Table 1 for the description of respective simulator.

\subsection{Numerical models and discretization of the problem}

The numerical methods and discretization of the near-field model are presented in Column 2 of Table 3. These numerical methods were selected not because one particular method was deemed better than others, but because these are the existing numerical simulators developed by or used by the respective research teams in their regular scientific or engineering work. Many of the simulators have been extensively applied in previous DECOVALEX projects as well as in national nuclear waste programs (Table 1). It is recognized that each numerical method may be suitable for analyzing different aspects of the EDZ evolution at different scales, e.g., at the scale of a wall-block domain, a near-field domain, or a full three-dimensional repository domain.

The research teams used different methods to discretize and represent fractures in the wall-block and near-field models. The discretization of the near field model domain with fractures was most challenging and interesting, as different ways of simplifying the network had to be employed by the different teams. The original fracture geometry of the near-field model domain, shown in Fig. 2b, was derived from detailed fracture mapping at the Äspö Hard Rock Laboratory (See Hudson 
et al. 2008). The mapped fractures include natural (pre-existing) fractures as well as fractures adjacent to the excavation wall that have been induced by the excavation process (smooth blasting).

LBNL-DOE and CAS discretized the geometry into a fine mesh, with fractures represented by softening and weakening grid elements intersected by a fracture trace. The softening effect of an intersecting fracture trace was represented by a simple one-dimensional formula considering fracture stiffness (Young's modulus of intact rock) and grid size. Moreover, in the case of elastoplastic analysis, the weak elements were assigned Mohr-Coulomb properties with very low cohesion (1 MPa) and friction angle of $27^{\circ}$. Although isotropic elastic and elasto-plastic models were applied, anisotropic fracture deformation behavior can still be achieved, because most substantial shear and normal deformation will automatically tend to occur, respectively, along and normal to the trace of weak fracture elements.

FRACOM and KTH-SKI simplified the fracture network to include only a subset of the entire fracture network and assumed planar fractures. KTH-SKI represented fractures by breaking the bonds between particles aligned along the trace of the fractures in their particle mechanics approach.

The JAEA research team used a continuum damage model without explicit representation of fractures. Initial damage was assigned to a region around the drift to represent the reduced rockmass modulus as estimated from in situ seismic velocity measurements. Outside this damaged 
region, the rock was initially assumed undamaged, with a deformation modulus equal to that of intact rock.

\subsection{Approach for Assessing Evolution of Damage and Permeability}

Each team used different approaches to assess the evolution of damage and permeability in the EDZ, depending on their respective numerical method (Table 3, column 3). FRACOM evaluated damage by investigating crack propagation in their BEM analysis, with permeability calculated from the cubic law based on the current aperture in fracture elements. In the wall-block model domain, FRACOM also investigated creation of new macrofractures in the rock matrix. In their particle mechanics model, KTH-SKI evaluated damage by investigating the evolution in breakage of particle bonds, but did not evaluate permeability evolution. JAEA simulated damage in the near-field model using a continuum damage model, with permeability related to aperture changes in the crack tensor estimated from the volumetric strain. LBNL-DOE used a simple empirical stress- and strain-versus-permeability relationship to model the evolution of permeability. CAS used a similar approach, a strain-versus-permeability relationship, with damage (fracture shear or matrix rock failure) evaluated using the Mohr-Coulomb elasto-plastic model.

These different approaches to determine relevant, but hard to obtain input parameters, were employed according to the different modeling approaches used. The JAEA, KTH-SKI, and FRACOM teams used results from previous analyses of small-scale laboratory experiments on rock samples collected from the Äspö Hard Rock Laboratory (Bäckström et al. 2008, Rinne and Shen 2008). The JAEA used the laboratory data to calibrate their continuum damage parameters. KTH-SKI used the same data for calibrating micromechanical parameters (i.e., bond stiffness and 
strength properties). FRACOM used laboratory data to validate and test their fracture mechanics models; FRACOM also conducted additional laboratory experiments to determine fracture toughness parameters for their fracture propagation analysis (Bäckström et al. 2008).

LBNL-DOE and CAS used a completely different approach for deriving the necessary input parameters. LBNL-DOE did not use the laboratory data, but instead relied on field studies of EDZ performed in crystalline rock sites at Äspö in Sweden (e.g., Emsley et al. 1997) and at URL in Canada (e.g., Martin 2005) to calibrate their strain-versus-permeability function. The strainversus-permeability function was first calibrated to yield reasonable changes after excavation of the drift; a permeability change of one to two orders of magnitude upon excavation. Thereafter, the evolution of permeability during heating was predicted using the calibrated model. This approach was justified by the fact that there might be serious scaling issues when using the smallscale laboratory data for prediction of the drift-scale evolution of damage and permeability. For example, studies at both URL and Äspö have shown that the in situ strength is about $50 \%$ of the short-term peak strength measured from laboratory experiments (Martin 2005). CAS did not utilize their results from their previous analysis of the small-scale laboratory experiments (Bäckström et al. 2008), but rather used a standard Mohr-Coulomb strength model. The MohrCoulomb parameters for the matrix rock were set relatively low, to reflect potential scale dependency, and low cohesion and friction angle were applied for the fracture elements.

\subsection{Approaches for Assessment of Time-Dependent Effects}

In this study, a few modeling approaches were explored for consideration of time dependency (Table 3, column 4). JAEA investigated time-dependent strength reduction by considering a case of so-called intensified damage, in which the damage parameters were lowered (resulting in a 
lower damage threshold and lower peak strength) and that such intensified damage would occur progressively due to chemical interaction during the first 100 years. The KTH-SKI research team investigated potential time-dependent effects on the homogenous wall-block model domain by assuming an exponential decline in bond strength. With the assumed function, the bond strength was not significantly reduced at 100 years, but was reduced by a factor of 0.8 at 10,000 years and further to a factor 0.1 at 100,000 years. The FRACOM research team conducted the most elaborate and rigorous analysis of potential time-dependent strength degradation, by considering subcritical crack growth in their BEM analysis. The parameters dictating the time-dependent subcritical crack growth were determined from laboratory experiments under water-saturated and saline conditions (Bäckström et al. 2008). This analysis was applied to model potential timedependent subcritical crack growth in both the near-field model and wall-block model.

\section{Simulation Results for EDZ Evolution}

A large number of simulations were performed by each research team on both the wall-block and near-field model domains. Here, we present a few selected results, focused on the evolution of stress, failure, and permeability, and on the assessment of time-dependent processes.

\subsection{Evolution of Stress, Failure and Permeability}

Figure $3 \mathrm{~b}$ shows that the maximum stress (i.e., potentially the most severe conditions) for creating stress-induced changes in the EDZ occurs between 50 to 100 years after emplacement.

Figure 4 presents the contours of maximum and minimum principal stresses at 100 years, i.e., at peak stress. The heterogeneity in the stress field is caused by the effects of fractures, because 
these represent soft and weak traces in the rock mass. We also observe a zone of negative (tensile) minimum principal stress near the spring line (Fig. 4b).

Figure 5 shows an assessment of potential permeability changes by the LBNL-DOE team. These results were developed using the LBNL-DOE model shown in Table 3, in which the permeability changes were correlated to volumetric and deviatoric strain according to:

$$
k=\left[k_{i}+\Delta k_{\max } \exp \left(\beta \Delta \varepsilon_{v}\right)\right] \cdot \exp \left(\gamma \Delta \varepsilon_{d}\right)
$$

where $k_{i}$ is initial permeability, and $\Delta k_{\max }, \beta$, and $\gamma$ are fitting parameters. Moreover, in Equation (1) $\Delta \varepsilon_{v}$ is change in volumetric strain relative to initial volumetric strain before excavation, i.e. $\Delta \varepsilon_{v}=\varepsilon_{v}-\varepsilon_{v}\left(\right.$ initial), whereas $\Delta \varepsilon_{d}$ is deviatoric strain relative to a critical deviatoric strain for the onset of shear dilation, i.e. $\Delta \varepsilon_{d}=\varepsilon_{d}-\varepsilon_{d}($ critical). The parameters in Equation (1) were calibrated to produce reasonable permeability changes as observed near excavated tunnels, in particular at the URL, in Canada, leading to a set of parameters presented in Table 4 (Rutqvist et al. 2008c).

Figure 5 shows substantial changes in permeability near the top of the tunnel, caused by large deviatoric strain. At the springline, there is also an increase in permeability caused by a volumetric expansion related to a general reduction in mean stress. The magnitude of permeability changes depends on the calibrated parameters, whereas the trends may be considered largely insensitive to the exact parameter values. The general trend is that after emplacement, the change near the top of the drift would further increase and extend as a result of further increase in deviatoric stress and strain during the first 100 years. If failure occurs during this period of time (e.g., shear failure and propagation of pre-existing fractures), a large part of 
the induced permeability changes would be permanent. That is, they would remain after the temperature has declined to ambient, and thermal stresses have vanished.

Significant inelastic behavior and rock failure were predicted near the drift wall by many research teams, but only if fractures or scale-dependent strength parameters were considered. The calculated peak stress of about $100 \mathrm{MPa}$ at the top of the drift in Fig. 4 is substantially lower than the short-term peak strength determined from small scale core samples (about $280 \mathrm{MPa}$ ). Thus, macroscopic failure in the intact rock could only occur assuming an in situ strength that is a fraction (e.g., about $50 \%$ or less) of the small-scale short-term peak strength. For example, using a damage model with damage parameters calibrated from laboratory data, JAEA predicted only very limited and localized damage near the drift wall. KTH-SKI predicted no significant failure using their particle-mechanics model, in which the micromechanical parameters had been calibrated against results from small-scale laboratory tests. FRACOM predicted some propagation and coalescence of fractures during the excavation phase, which could produce increased connectivity in the flow path (Fig. 6a). CAS predicted a rather extensive zone of failure, both in the fractures and rock matrix (Fig. 6b) when using rather conservative (low) strength parameters, including a uniaxial compressive strength on the order of $80 \mathrm{MPa}$ for the intact matrix. The zone of failure largely coincides with a zone of high deviatoric (shear) stress, although some tensile failure may also play a role, especially near the spring line of the drift.

The evolution of failure was also studied in the wall-block model, which represents the highest stressed area around the drift and which considers small-scale fracturing. For example, Fig. 7 shows the evolution of damage caused by initiation of new fractures as well as propagation on 
pre-existing fractures calculated by the FRACOM research team using the BEM method. The results show that most failure occurs during the first 100 years, when the horizontal stress approaches $100 \mathrm{MPa}$. However, the induced fracturing in this model had a very limited effect on the overall stress-strain behavior of the wall block, which was only weakly nonlinear over the 100,000 year simulation time.

\section{Assessment of Time-Dependent Effects}

Time-dependent effects could include chemically mediated mechanical processes such as subcritical crack growth, stress- and temperature-induced pressure solution and stress corrosion, leading to time-dependent strength degradation. In this study, the few modeling attempts to assess the time-dependent effects indicated a very limited impact on mechanical behavior for this particular simulation problem. In particular, KTH-SKI and JAEA showed that limited damage would occur once the strength reduced by about $50 \%$ of the short-term strength. Likewise, CAS found very limited impact of time dependency using their elasto-viscoplastic constitutive model. The more elaborate analysis by FRACOM's research team showed only insignificant subcritical crack growth, which occurred during the first 100 years of thermal loading. After 100 years, the calculated maximum principal stress declines, and therefore the rate of subcritical crack growth also declines.

The issue of time dependency may be illustrated by plotting the evolution of the maximum principal stress at the top of the emplacement drift and the estimated evolution of the degrading 
uniaxial compressive strength (Fig. 8). Studies at URL in Canada and elsewhere indicate that rock strength reduces logarithmically with time to failure, but the strength reduction levels out within a month. Therefore, time-dependency might be accounted for by reducing the long-term in situ strength by about $50 \%$ of the strength obtained from short-term laboratory tests. However, the issue of the relevance of time dependency for the evolution of the EDZ over 100,000 years is unclear, because of there is still a lack data and models to evaluate such changes.

\section{Concluding Remarks}

In this simulation problem, we have demonstrated how widely different modeling approaches can be adapted to simulate the evolution of EDZ around a heat-releasing nuclear waste emplacement drift in fractured rock. Each modeling approach has their special capabilities for studying different aspects of the EDZ evolution at different scales. The heterogeneous FEM and EPCA methods, with representation of fractures through weak elements, are very useful for a simplified yet complete analysis of EDZ changes in both a complex fracture network and surrounding matrix rock. The BEM method, using discrete fracture propagation is currently the most rigorous method for quantitative assessment of time-dependent strength-degradation effects based on crack propagation theories. The particle-mechanics method is probably more suitable for studying failure processes at the smallest (laboratory) scale than at tunnel scale, but may also be applied to the tunnel scale if the micromechanical parameters can be properly calibrated. This method is also very promising for considering physically based strength reduction through chemically mediated changes in bond strength. However, we should also remember that the above approaches were applied on two-dimensional model domains. In a full three-dimensional domain, it would be computationally very demanding to represent the complex fracture network 
explicitly. Hence, for a full three-dimensional analysis, the FEM continuum damage model may be the most practical option.

To make any reasonable assessment of the EDZ evolution, the above models need to be supplied with proper input data. Such data would include laboratory data needed to determine parameters such as crack initiation and fracture toughness for the BEM method, and for calibration of micromechanical parameters for the particle-mechanics method. Moreover, field data, including detailed measurements of fracturing, permeability, and mechanical changes that can be used to calibrate and validate respective model will be essential. In situ data are very important for considering the scale dependency of strength parameters and for assessing the effects of fractures. Moreover, in situ measurements of permeability should ideally be sufficiently detailed and comprehensive enough to capture localized changes in fracture planes or at fracture intersections, which may be critical to flow and transport along the EDZ.

If the models are properly calibrated and validated after excavation, then one can probably make a reasonable estimate of how the EDZ will progress during the initial heating period after emplacement. Our analysis of this specific simulation problem indicated that increased differential stresses near the top of the emplacement drift during the first 100 years may cause additional failure and permeability changes. Moreover, the results of this specific simulation problem indicated that time dependency may play only a small role during the first 100 years of loading, which is a relatively short time for chemically mediated processes. Without the heat load, the maximum principal stress is about $60 \mathrm{MPa}$ (about $20 \%$ of the small-scale peak strength), which may be too small to induce significant time-dependent mechanical changes. 
However, predictions of chemically mediated time-dependent mechanical change over a 100,000-year period are still very uncertain, but could be conservatively bounded. This would include consideration of time-dependent pressure solution of fracture asperities and its effect on fracture permeability under elevated temperature and stress (Min et al. 2008). Bounds of such chemically-mediated effects could be better constrained using fully coupled THMC models, considering limiting reaction rates. Although several promising attempts were made to model coupled THMC processes in this study, including chemically mediated time-dependent processes, fully coupled THMC models are still lacking.

\section{Acknowledgments}

Funding for the work performed by the LBNL research team and the first author was provided to LBNL by the U.S. Department of Energy under Contract No. DE-AC02-05CH11231. The United States Government retains and the publisher, by accepting the article for publication, acknowledges that the United States Government retains a non-exclusive, paid-up, irrevocable, world-wide license to publish or reproduce the published form of this manuscript, or allow others to do so, for United States Government purposes. Funding for modeling work by other research teams was provided by Japanese Atomic Energy Agency (JAEA), the Finnish Research Programme on Nuclear Waste Management (KYT) and Posiva, the Swedish Nuclear Power Inspectorate (SKI), and the National Nature Science Foundation of China under grant No. 50709036 and 40520130315. 
It is emphasized that the views expressed in this paper are solely those of the authors and cannot necessarily be taken to represent the views of any of the organizations listed above.

\section{References}

Bäckblom G, Martin CD (1999) Recent experiments in hard rock to study the excavation response: Implication of the performance of a nuclear waste geological repository. Tunneling and Underground Space Technology 14:377-394.

Bäckström A, Antikainen J, Backers T, Feng Xiating, Jing Lanru, Kobayashi A, Koyama T, Pan Pengzhi, Rinne M, Shen Baotang, Hudson JA (2008) Numerical modelling of uniaxial compressive failure of granite with and without saline porewater. Int J Rock Mech \& Min Sci 43:1091-1108.

Chijimatsu M, Nguyen TS, Jing L, de Jonge J, Kohlmeier M, Millard A, Rejeb A, Rutqvist J, Souley M, Sugita Y (2005) Numerical study of the THM effects on the near-field safety of a hypothetical nuclear waste repository - BMT1 of the DECOVALEX III project. Part 1: Conceptualization and characterization of the problems and summary of results. Int. J Rock mech \& Min Sci 42:720-730.

Emsley S, Olsson O, Stenberg L, Alheid H-J, Fall S (1997) ZEDEX - a study of damage and disturbance from tunnel excavation by blasting and tunnel boring. Swedish Nuclear Fuel and Waste Management Co (SKB) Technical Report 97-30, Stockholm.

Feng Xia-Ting, Pan Peng-zhi, Zhou Hui (2006) Simulation of rock microfracturing process under uniaxial compression using elasto-plastic cellular automata. Int J Rock Mech \& Min Sci 43: 1091-1108.

Hudson JA, Bäckström A, Rutqvist J, Jing L, Backers T, Chijimatsu M, Feng X-T, Kobayashi A, Koyama T, Lee H-S, Pan P-Z, Rinne M, Shen B (2008) Characterization and modeling the excavation damaged zone (EDZ) in crystalline rock in the context of radioactive waste disposal. Environ Geol (this issue)

Kobayashi A, Fujita T, Chijimatsu M. Continuous approach for coupled mechanical and hydraulic behavior of fractured rock mass during hypothetical shaft sinking at Sellafield, UK. Int J Rock Mech \& Min Sci 31: 45-57.

Martin D (2005) Preliminary assessment of potential underground stability (wedge and spalling) at Forsmark, Simpevarp and Laxemar sites. SKB report R-05-71.

Min KB, Rutqvist J, Elsworth D (2008) Chemically- and mechanically-mediated influences on the transport and mechanical characteristics of rock fractures. Int J Rock Mech \& Min Sci (Accepted for publication, April 2008). 
Nguyen TS, Börgesson L, Chijimatsu M, Rutqvist J, Fujita T, Hernelin J, Kobayashi A, Onishi Y, Tanaka M, Jing L (2001) Hydro-mechanical response of a fractured rock mass to excavation of a test pit - The Kamaishi Mine Experiment in Japan. Int J Rock Mech \& Min Sci 38:79-94.

Noorishad J, Tsang C-F (1996) ROCMAS-simulator: A Thermohydromechanical Computer Code. In Stephansson, O., Jing, L., and Tsang, C.-F. editors. Coupled Thermo-hydromechanical Processes of Fractured Media. Developments in Geotechnical Engineering, Elsevier, 79, pp. 551-558.

Ohnishi Y, Shibata H, Kobayashi A (1987) Development of finite element code for the analysis of coupled thermo-hydro-mechanical behavior of a saturated-unsaturated medium. In C.-F. Tsang, editor, Coupled Processes Associated with Nuclear Waste Repositories, Academic Press, 551-557.

Ohnishi Y, Kobayashi A (1996) THAMES. In O. Stephansson, L. Jing, and C.-F. Tsang, editors, Coupled Thermo-hydro-mechanical Processes of Fractured Media, Developments in Geotechnical Engineering, Elsevier, 79:545-549.

Pan Peng-zhi, Feng Xia-ting, Hudson JA (2006a) Simulations on Class I and Class II curves by using the linear combination of stress and strain control method and elasto-plastic cellular automata . Int J Rock Mech and Min Sci 43:1109-1117.

Pan Peng-zhi, Feng Xia-ting, Zhou Hui (2006b) Simulation of rock fracturing in an HM coupling environment using a cellular automaton. In Proceedings of the GEOPROC2006 International symposium: $2^{\text {nd }}$ International Conference on Coupled Thermo-hydromechanical-chemical processes in Geosystems and Engineering, HoHai University, Nanjing, China, May 22-25, 2006, p. 503-508.

Pan Peng-zhi, Feng Xia-Ting, Huang Xiao-Hua, Cui Qiang, Zhou Hui (2008) Study of coupled THMC processes in crystalline rock in the EDZ using an ECPA code. Environmental Geology (this issue).

Potyondy DO, Cundall PA (2004) A bonded-particle model for rock. Int J Rock mech \& Min Sci. 42:1329-1364.

Rinne M, Shen B (2008) Long-term Response of Near-field BMT Models around a Deposition Hole by BEM - Modeling discrete fracturing of EDZ. Accepted to be published in the proceedings of the 3rd International Conference on Coupled T-H-M-C Processes in Geosystems, GeoProc 2008, June 2-6, 2008, Lille, France.

Rutqvist J, Stephansson O (2003) The role of hydromechanical coupling in fractured rock engineering. Hydrogeology Journal 11:7-40.

Rutqvist J, CF Tsang (2003) Analysis of thermal-hydrologic-mechanical behavior near an emplacement drift at Yucca Mountain. Journal of Contaminant Hydrology 62-63:637-652.

Rutqvist J, Börgesson L, Chijimatsu M, Kobayashi A, Nguyen TS, Jing L, Noorishad J,Tsang CF (2001a) Thermohydromechanics of partially saturated geological media - Governing equations and formulation of four finite element models. Int J Rock Mech Min Sci 38:105127. 
Rutqvist J, Börgesson L, Chijimatsu M, Nguyen TS, Jing L, Noorishad J, Tsang CF (2001b) Coupled thermo-hydro-mechanical analysis of a heater test in fractured rock and bentonite at Kamaishi Mine - Comparison of field results to predictions of four finite element codes. Int J Rock Mech \& Min Sci 38:129-142.

Rutqvist J, Wu YS, Tsang C-F, Bodvarsson G (2002) A modeling approach for analysis of coupled multiphase fluid flow, heat transfer, and deformation in fractured porous rock. Int J Rock mech \& Min Sci 39:429-442.

Rutqvist J, Barr D, Datta R, Gens A, Millard M, Olivella S, Tsang C-F, Tsang Y (2005a) Coupled thermal-hydrological-mechanical analysis of the Yucca Mountain Drift Scale Test - comparison of field results to predictions of four different models. Int J Rock Mech \& Min Sci 42:680-697.

Rutqvist J, Chijimatsu M, Jing L, de Jonge J, Kohlmeier M, Millard A, Nguyen TS, Rejeb A, Souley M, Sugita Y, Tsang C-F. (2005b) Numerical study of the THM effects on the nearfield safety of a hypothetical nuclear waste repository - BMT1 of the DECOVALEX III project. Part 3: Effects of THM coupling in fractured rock. Int J Rock Mech \& Min Sci 42:745-755.

Rutqvist J, Bäckström A, Lanru J, Hudson JA (2008a) A Benchamark simulation study of coupled THMC processes in the excavation disturbed zone associated with geological nuclear waste repositories. Final report of DECOVALEX-THMC Task B, Phase 3, SKI Technical Report (in press).

Rutqvist J, Barr D, Birkholzer JT, Fujisaki K, Kolditz O, Liu Quan-Sheng, Fujita T, Wang Wenqing, Cheng-Yuan Zhang (2008b) A comparative simulation study of coupled THM processes and their effect on fractured rock permeability around nuclear waste repositories. Environmental Geology (this issue).

Rutqvist J, Börgesson L, Chijimatsu M, Hernelind J, Jing L, Kobayashi A, Nguyen S (2008c) Modeling of Damage, Permeability Changes and Pressure Responses during Excavation of the TSX Tunnel in Granitic Rock at URL, Canada. Environmental Geology (this issue).

Shen B, Stephansson O (1993) Numerical analysis of mixed mode-I and mode-II fracture propagation. Int J Rock mech \& Min Sci 30:861-867.

Shen B, Rinne M, Stephansson O, 2006. FRACOD2D. User's Manual ver 2.21, 2006. Fracom Ltd.

SKB (2006) Long-term safety for KBS-3 repository at Forsmark and Laxemar - a first evaluation. Main report of the SR-Can project. SKB TR-06-09. Swedish Nuclear Fuel and Waste Management Co, Stockholm, Sweden.

Sugihara K, Matsu H and Sato T (1999) In situ experiments on rock stress conditions and excavation disturbance in JNC's geoscientific research program in Japan. In: Saeb S and Francke C (eds) Rock Mechanics of Nuclear Waste Repositories, Veil, Colorado. pp. 159183.

Tsang Chin-Fu, Bernier F, C. Davies (2005) Geohydromechanical processes in the Excavation Damaged Zone in crystalline rock, rock salt, and indurated and plastic clays-in the context of radioactive waste disposal. . Int J Rock mech \& Min Sci 42:109-125. 
Witherspoon P A (2000) The Stripa project. Int J Rock Mech \& Min Sci 37:385-396. Lee H-S, 
Table 1. Research teams and simulators applied in this study

\begin{tabular}{|c|c|c|}
\hline Research Team & $\begin{array}{l}\text { Numerical } \\
\text { Simulator }\end{array}$ & Brief Description of Numerical Simulator \\
\hline \multirow[t]{2}{*}{$\begin{array}{l}\text { LBNL-DOE: Lawrence } \\
\text { Berkeley National } \\
\text { Laboratory (LBNL) } \\
\text { research team funded by } \\
\text { the U.S. Department of } \\
\text { Energy. }\end{array}$} & $\begin{array}{l}\text { TOUGH- } \\
\text { FLAC }\end{array}$ & $\begin{array}{l}\text { TOUGH-FLAC is a simulator for analysis of coupled THM processes } \\
\text { under multiphase fluid flow conditions developed at the LBNL in the } \\
\text { last few years (Rutqvist and others 2002). The simulator is based on } \\
\text { linking of the existing computer codes TOUGH2 and FLAC3D. It has } \\
\text { been extensively used for analysis of coupled THM processes within the } \\
\text { Yucca Mountain Project (Rutqvist and Tsang 2003; Rutqvist and others } \\
\text { 2005a). }\end{array}$ \\
\hline & ROCMAS & $\begin{array}{l}\text { ROCMAS is a finite element program for analysis of coupled THM } \\
\text { processes in porous and fractured rock developed at LBNL since the late } \\
\text { 1980s (Noorishad and Tsang 1996; Rutqvist and others 2001a). In the } \\
\text { late 1990s, this code was extended to unsaturated media with single- } \\
\text { phase liquid flow and vapor diffusion in a static gas phase. The code has } \\
\text { been extensively applied in earlier phases of the DECOVALEX project } \\
\text { for THM analysis in bentonite-rock systems (Nguyen and others 2001; } \\
\text { Rutqvist and others 2001b; Rutqvist and other. 2005b). }\end{array}$ \\
\hline $\begin{array}{l}\text { CAS: Chinese Academy } \\
\text { of Sciences' Research } \\
\text { Team }\end{array}$ & EPCA & $\begin{array}{l}\text { The EPCA code (Elasto-Plastic Cellular Automata) uses the concept of } \\
\text { cellular automata inspired by the self-organizing theory in biology. This } \\
\text { code has been successfully used to simulate the failure process of } \\
\text { heterogeneous rocks with and without consideration of hydro- } \\
\text { mechanical coupling (Feng and others 2006; Pan and others 2006a; Pan } \\
\text { and others 2006b). The code is described in more detail in } \\
\text { accompanying paper by Pan and others (2008). }\end{array}$ \\
\hline $\begin{array}{l}\text { FRACOM: FRACOM } \\
\text { Ltd, Finland. Korea, } \\
\text { Australia }\end{array}$ & FRACOD & $\begin{array}{l}\text { The two-dimensional boundary element (BEM) code FRACOD is based } \\
\text { on the Displacement Discontinuity Method (Shen and others 2006). The } \\
\text { model predicts the explicit failure process, including fracture initiation, } \\
\text { fracture sliding/opening, fracture propagation, and fracture coalescence. } \\
\text { Fracture propagation is modeled using the F-criterion suggested by Shen } \\
\text { and Stephansson (1993). A creep model based on the subcritical crack } \\
\text { growth theory has been implemented in FRACOD to evaluate the time- } \\
\text { dependent mechanical effects. }\end{array}$ \\
\hline $\begin{array}{l}\text { JAEA: Japan Atomic } \\
\text { Energy Agency's } \\
\text { Research Team, } \\
\text { including Hazama } \\
\text { Cooperation }\end{array}$ & THAMES & $\begin{array}{l}\text { THAMES is a finite-element code to simulate coupled THM behavior in } \\
\text { a fully or partially saturated medium developed at Kyoto University, } \\
\text { Japan (e.g., Ohnishi and others 1987). Recent development involves } \\
\text { consideration of anisotropic permeability and stiffness of fractured rock } \\
\text { using Oda's crack tensor theory (Kobayashi and others 2001). This code } \\
\text { has been extensively applied in the DECOVALEX project and within } \\
\text { the Japanese nuclear waste program (e.g., Chijimatsu and others 2005). } \\
\text { Along with the study presented in this report, a continuum-damage } \\
\text { model was implemented. }\end{array}$ \\
\hline $\begin{array}{l}\text { KTH-SKI: Royal } \\
\text { Institute of Technology } \\
\text { (KTH), Stockholm, } \\
\text { funded by the Swedish } \\
\text { Nuclear Power } \\
\text { Inspectorate. }\end{array}$ & PFC & $\begin{array}{l}\text { PFC (Particle Flow Code), a code based on the discrete element method } \\
\text { (DEM), is commercially available and widely used in rock engineering } \\
\text { and academia (Potyondy and Cundall 2004). The rock system is } \\
\text { modeled by a system of particles bonded at their contact points that can } \\
\text { break to represent damage. The PFC is particularly useful in modeling } \\
\text { of damage and nonlinear mechanical behavior, but requires proper } \\
\text { calibration of micromechanical parameters, including bond strength and } \\
\text { stiffness. }\end{array}$ \\
\hline
\end{tabular}


Table 2. Basic rock properties for simulation of EDZ evolution

\begin{tabular}{|c|c|}
\hline \hline Parameter & Value \\
\hline \hline Density & $2,700 \mathrm{~kg} / \mathrm{m}^{3}$ \\
\hline Porosity & 0.01 \\
\hline Biot's constant & 1.0 \\
\hline Young's modulus & $70 \mathrm{GPa}$ \\
\hline Poissons ratio & 0.3 \\
\hline Thermal expansion coefficient & $1 \cdot 10^{-5}{ }^{\circ} \mathrm{C}^{-1}$ \\
\hline Permeability & $1 \times 10^{-19} \mathrm{~m}^{2}$ \\
\hline Initial hydraulic aperture & $10 \mu \mathrm{m}$ \\
\hline Residual hydraulic aperture & $3 \mu \mathrm{m}$ \\
\hline Normal stiffness & $2,000 \mathrm{GPa} / \mathrm{m}$ \\
\hline Shear stiffness & $200 \mathrm{GPa} / \mathrm{m}$ \\
\hline
\end{tabular}


Table 3. Main approaches used by each research team for modeling of EDZ evolution in the nearfield model domain

\begin{tabular}{|c|c|c|c|}
\hline $\begin{array}{l}\text { Research Team and } \\
\text { Near-Field Model } \\
\text { Geometry }\end{array}$ & $\begin{array}{l}\text { Numerical Methods and Model } \\
\text { Discretization }\end{array}$ & $\begin{array}{l}\text { Assessment of Damage } \\
\text { and Permeability } \\
\text { Evolution }\end{array}$ & $\begin{array}{l}\text { Assessment of Time- } \\
\text { dependent Effects }\end{array}$ \\
\hline LBN & $\begin{array}{l}\text { FDM (TOUGH-FLAC) and FEM } \\
\text { (ROCMAS) codes with model } \\
\text { domain discretized into a fine } \\
\text { mesh and representing the } \\
\text { fractures by softening and } \\
\text { weakening the grid elements } \\
\text { intersected by a fracture trace. }\end{array}$ & $\begin{array}{l}\text { Applied stress or strain- } \\
\text { versus-permeability } \\
\text { functions calibrated } \\
\text { against field } \\
\text { observations of EDZ in } \\
\text { crystalline rocks. }\end{array}$ & $\begin{array}{l}\text { Time dependent strength } \\
\text { degradation was ruled out } \\
\text { as insignificant based on } \\
\text { evolution of stress-to- } \\
\text { strength ratio and was } \\
\text { therefore not modeled. }\end{array}$ \\
\hline CAS & $\begin{array}{l}\text { EPCA code with model domain } \\
\text { discretized models into a fine } \\
\text { mesh and representing the } \\
\text { fractures by softening and } \\
\text { weakening the grid elements } \\
\text { intersected by a fracture trace. }\end{array}$ & $\begin{array}{l}\text { Applied a strain-versus- } \\
\text { permeability function } \\
\text { calibrated against field } \\
\text { observations of EDZ in } \\
\text { crystalline rocks. }\end{array}$ & $\begin{array}{l}\text { Considered time-dependent } \\
\text { effects through a visco- } \\
\text { elastic model calibrated to } \\
\text { literature data on granite. }\end{array}$ \\
\hline$\overline{\text { FR }}$ & $\begin{array}{l}\text { BEM code (FRACOD) with } \\
\text { fracture network simplified by } \\
\text { considering a subset of fractures } \\
\text { that were assumed to be perfectly } \\
\text { planar over their entire trace } \\
\text { length. }\end{array}$ & $\begin{array}{l}\text { Discrete crack } \\
\text { propagation, with } \\
\text { permeability calculated } \\
\text { from the cubic law based } \\
\text { on the current aperture in } \\
\text { fracture elements. }\end{array}$ & $\begin{array}{l}\text { Considering subcritical } \\
\text { crack growth with time- } \\
\text { dependent parameters } \\
\text { determined from laboratory } \\
\text { experiments under water } \\
\text { saturated and saline } \\
\text { conditions. }\end{array}$ \\
\hline & $\begin{array}{l}\text { PFC code with fractures } \\
\text { represented in particle-mechanics } \\
\text { model by breaking the bondage } \\
\text { between particles aligned along } \\
\text { the trace of the fractures. }\end{array}$ & $\begin{array}{l}\text { Damage simulated as } \\
\text { evolution in breakage of } \\
\text { particle bonds, but did } \\
\text { not evaluate permeability } \\
\text { evolution. }\end{array}$ & $\begin{array}{l}\text { Time-dependent effects } \\
\text { were considered in the } \\
\text { wall-block model domain } \\
\text { by a time-dependent } \\
\text { decline in bond strength, } \\
\text { but not applied on the near- } \\
\text { field model. }\end{array}$ \\
\hline JAE & $\begin{array}{l}\text { FEM code (THAMES) using } \\
\text { continuum damage model with } \\
\text { implicit representation of } \\
\text { fractures. Enhanced initial } \\
\text { damage was assigned in a region } \\
\text { around the tunnel to represent } \\
\text { damaged zone. }\end{array}$ & $\begin{array}{l}\text { Continuum damage } \\
\text { model, with permeability } \\
\text { related to aperture } \\
\text { changes estimated from } \\
\text { volumetric strain using } \\
\text { crack tensor theory. }\end{array}$ & $\begin{array}{l}\text { Considered time-dependent } \\
\text { strength reduction } \\
\text { assuming progressive } \\
\text { reduction in damage } \\
\text { parameters during the first } \\
100 \text { years. }\end{array}$ \\
\hline
\end{tabular}


Table 4. Final parameters used by the LBNL-DOE research team in their calibrated strain-versuspermeability functions for intact and fracture elements

\begin{tabular}{|l|c|c|}
\hline & Intact Rock Elements & Fracture Elements \\
\hline$K$ & $58.3 \mathrm{GPa}$ & $17.5 \mathrm{GPa}$ \\
\hline$G$ & $26.9 \mathrm{GPa}$ & $8.1 \mathrm{GPa}$ \\
\hline$\beta$ & $4.0 \cdot 10^{-7} \mathrm{~Pa}^{-1}$ & $4.0 \cdot 10^{-7} \mathrm{~Pa}^{-1}$ \\
\hline$\gamma$ & $3.0 \cdot 10^{-7} \mathrm{~Pa}^{-1}$ & $3.0 \cdot 10^{-7} \mathrm{~Pa}^{-1}$ \\
\hline$k_{i}$ & $1.3 \cdot 10^{-20} \mathrm{~m}^{2}$ & $1.4 \cdot 10^{-15} \mathrm{~m}^{2}$ \\
\hline$\Delta k_{\max }$ & $1.4 \cdot 10^{-18} \mathrm{~m}^{2}$ & $1.4 \cdot 10^{-12} \mathrm{~m}^{2}$ \\
\hline$\beta$ & 23320 & 7000 \\
\hline$\gamma$ & 16140 & 4860 \\
\hline
\end{tabular}




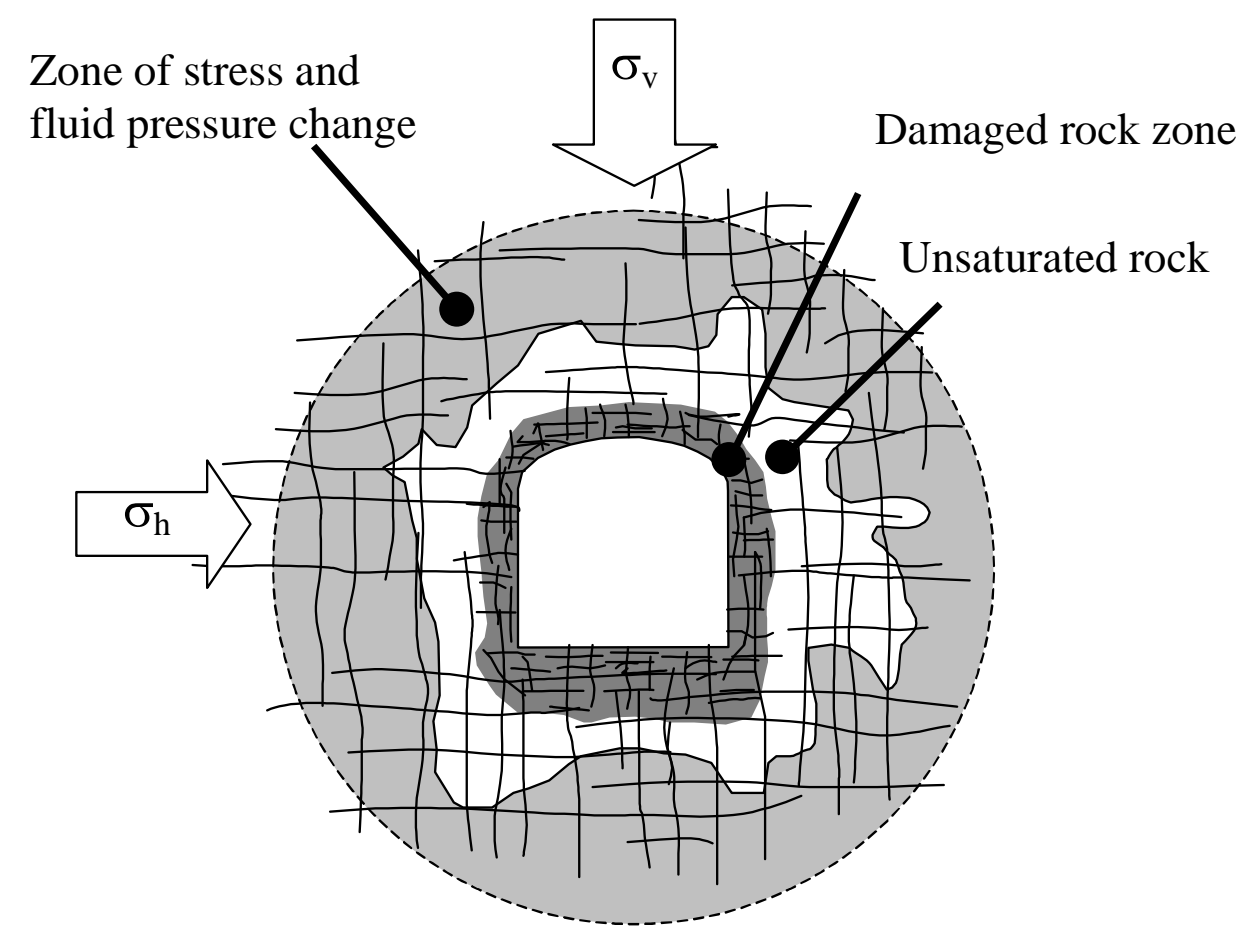

Figure 1. Schematic of the excavation disturbed zone (EDZ) around a drift in fractured rock (Rutqvist and Stephansson 2003) 

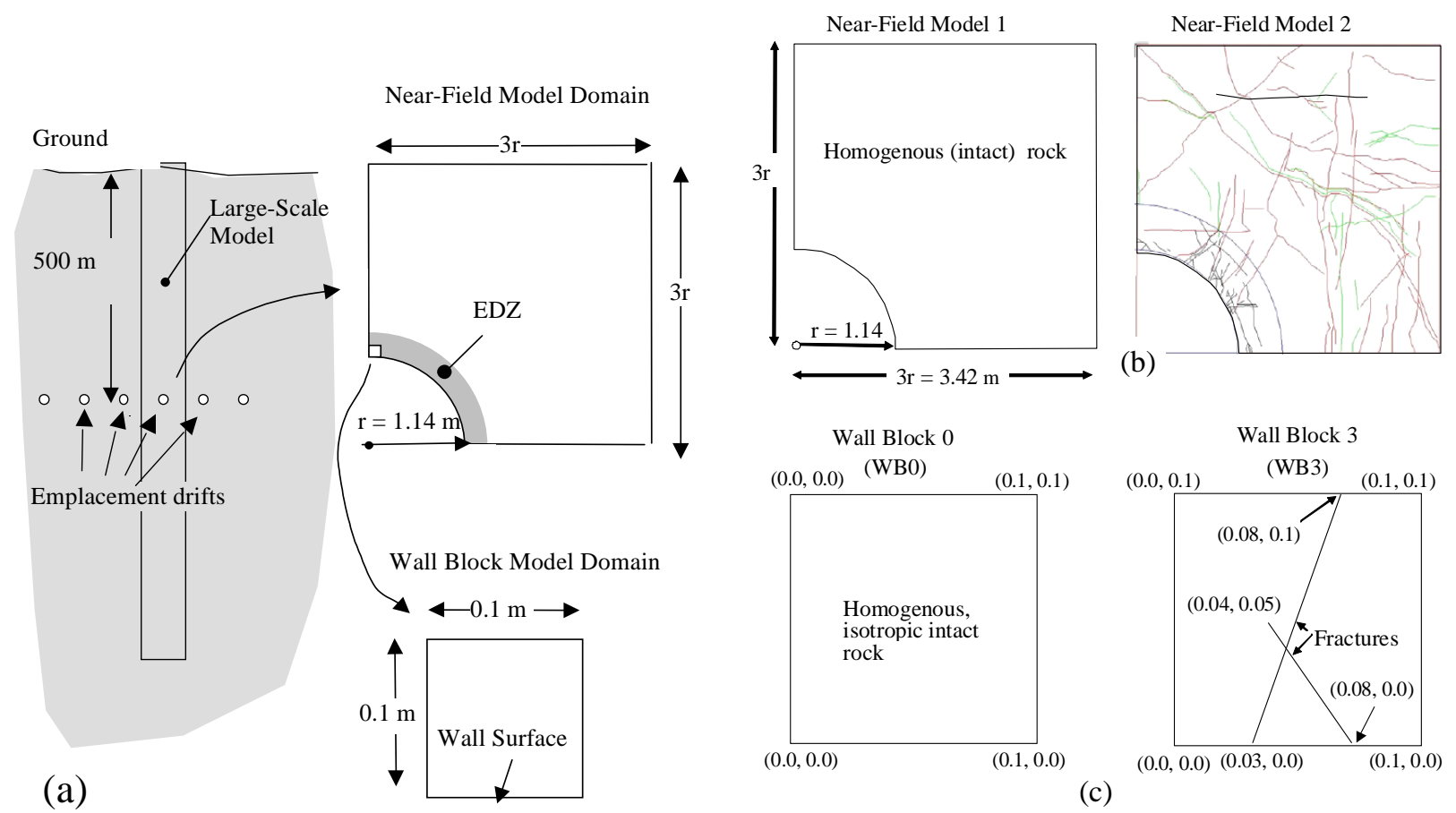

(c)

Figure 2. Two model domains considered for detailed modeling of the EDZ evolution around an emplacement drift in fractured rock: (a) locations of model domains, (b) geometry of near-field model domain with and without fractures and (c) geometry of a wall-block model domain with and without fractures 

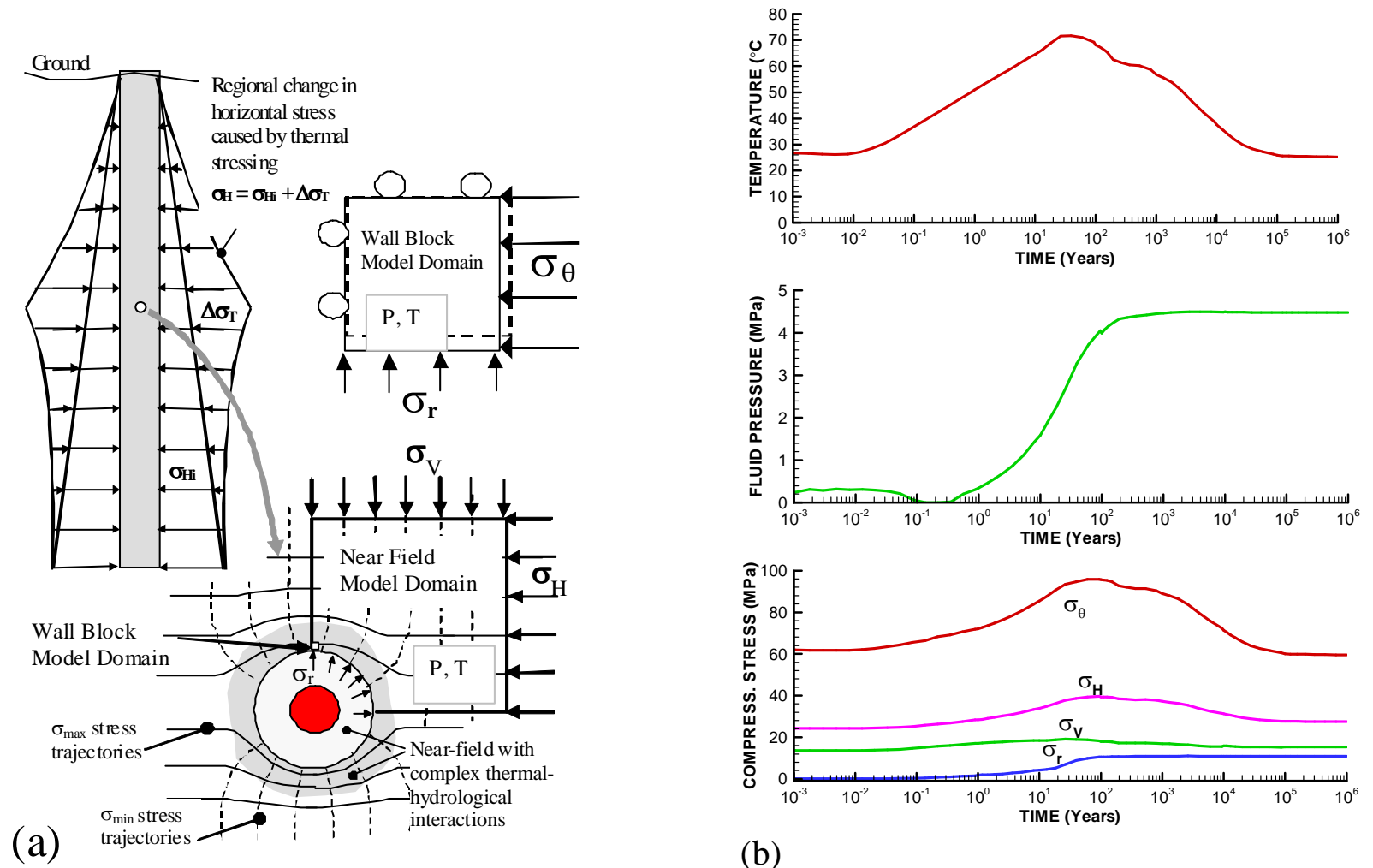

(b)

Figure 3. (a) Schematic showing derivation of boundary and interior conditions from a largescale model and (b) evolution of temperature, fluid pressure, and stresses applied to near-field and wall-block model domains. $t=0$ at emplacement of heat-releasing waste and bentonite. 


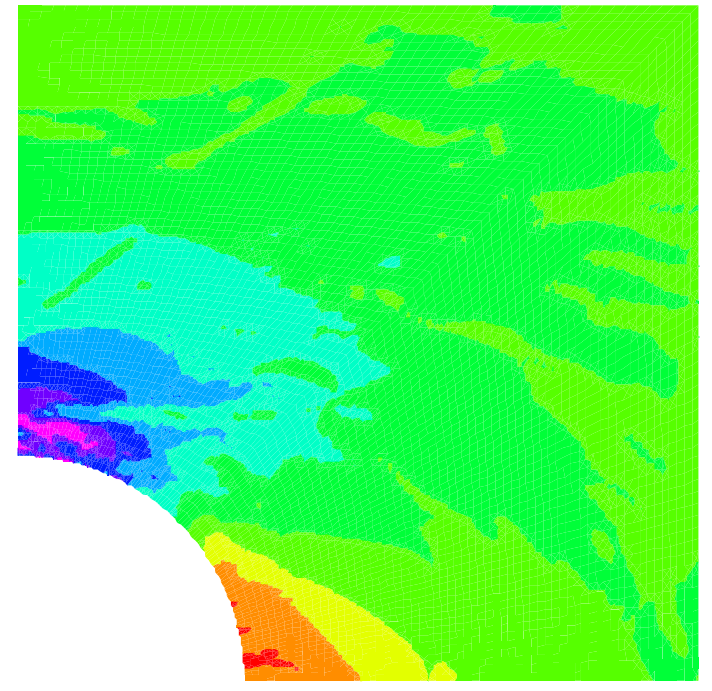

Maximum Compressive Stress (MPa)

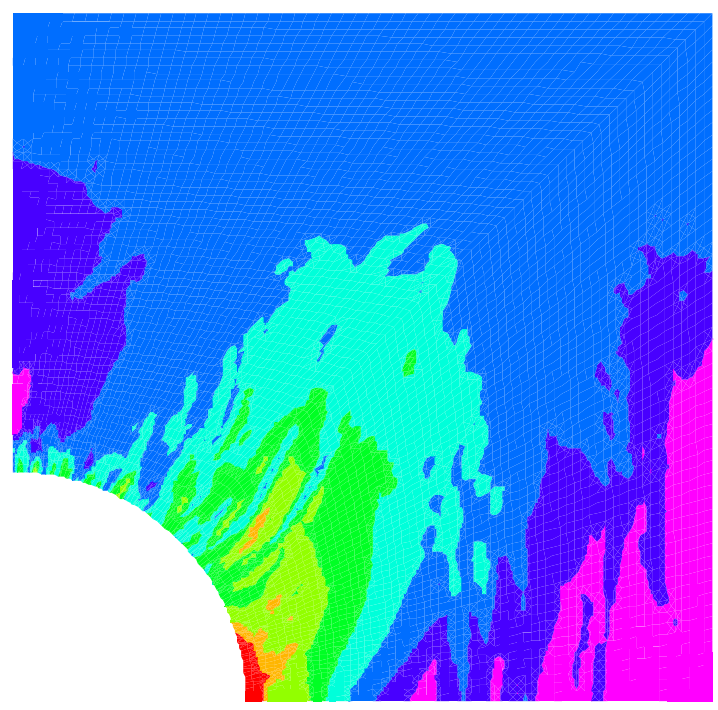

Minimum Compressive Stress (MPa) $\begin{array}{llllll}-10 & 0 & 10 & 20 & 30 & 40\end{array}$
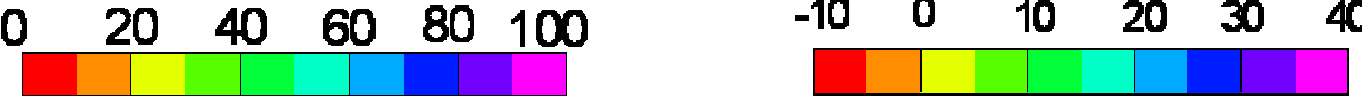

Figure 4. Maximum and minimum compressive stress at 100 years after emplacement (LBNLDOE model) 


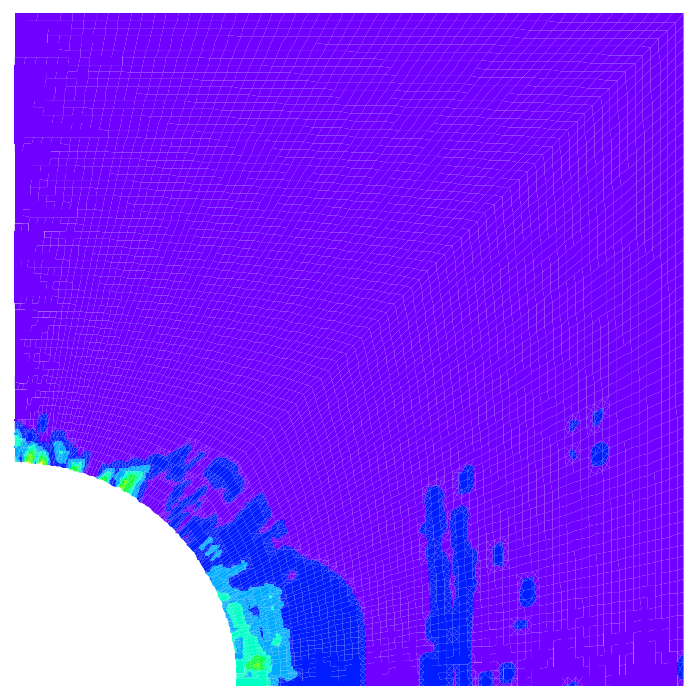

(a) At excavation

4.

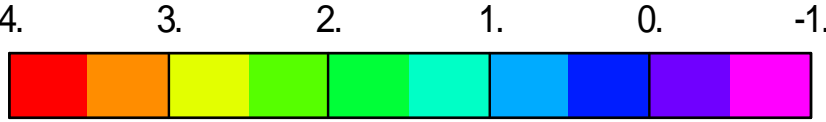

Figure 5. Permeability change $[\log (\mathrm{k} / \mathrm{ki})]$ (LBNL-DOE model) 

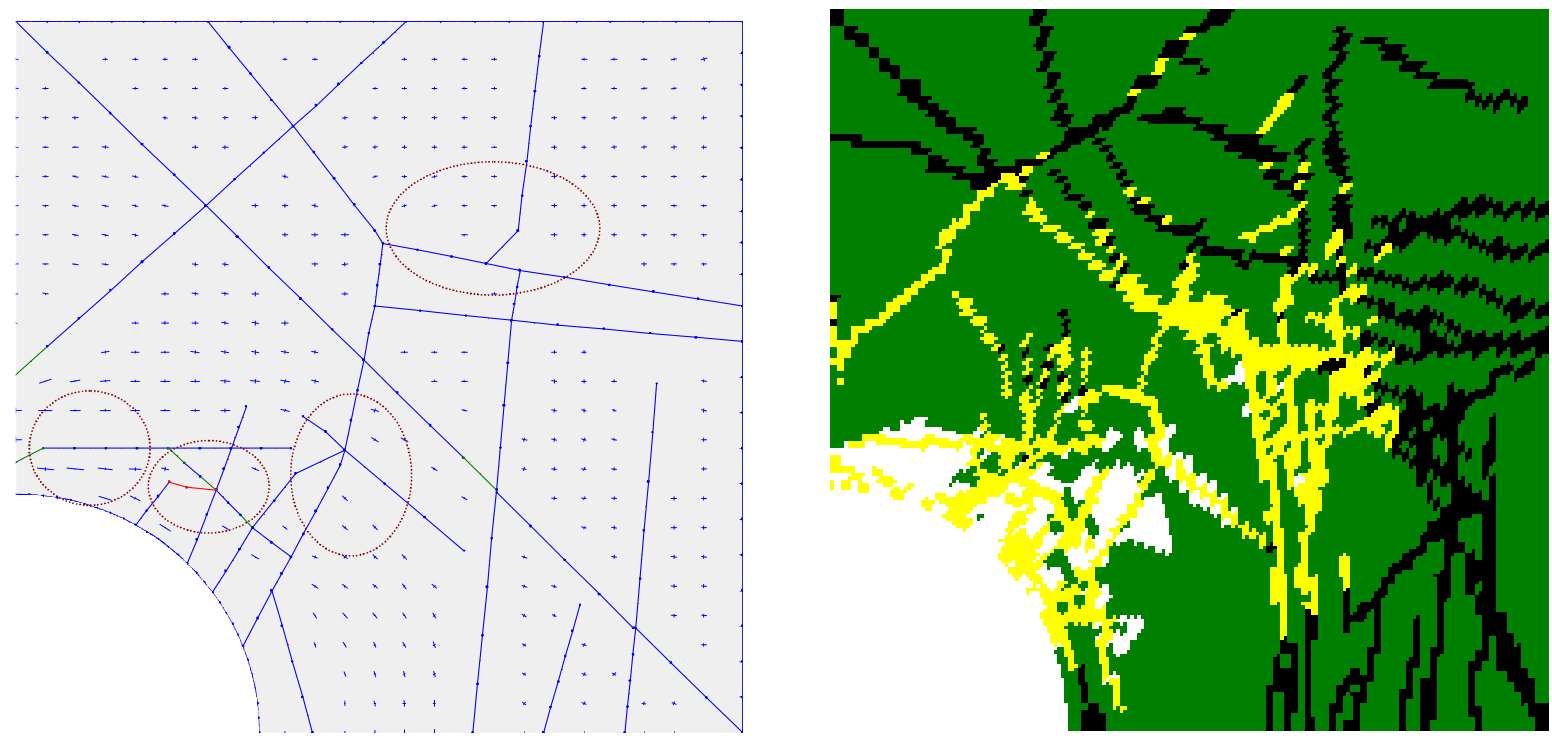

(a)

(b)

Figure 6. Calculated inelastic damage at 100 years after emplacement using: (a) locations of crack propagation in the FRACOM's BEM analysis (marked with dashed circles) and (b) locations of Mohr-Coulomb failure in the CAS EPCA analysis (marked with light colors) 


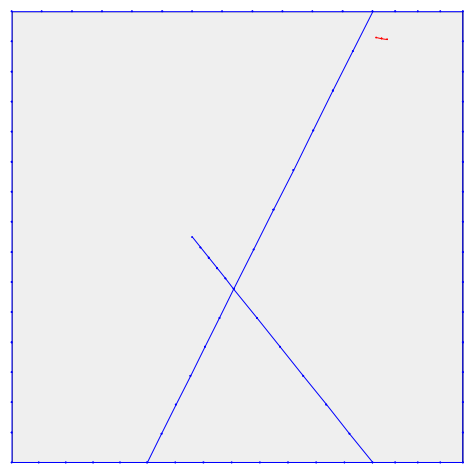

(a) Excavation

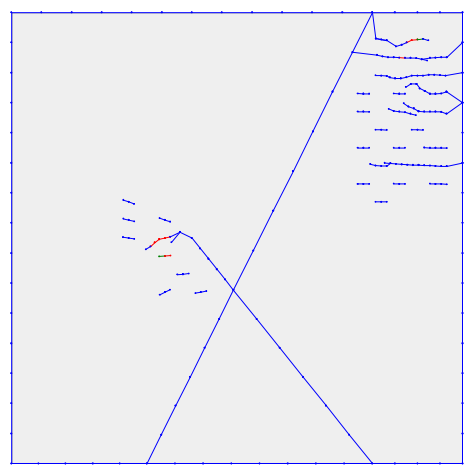

(b) 100 years

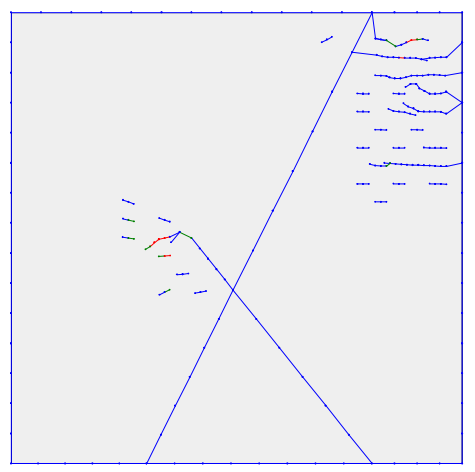

(c) 100,000 years

Figure 7. Evolution of failure in FRACOM's analysis of wall-block model 3 


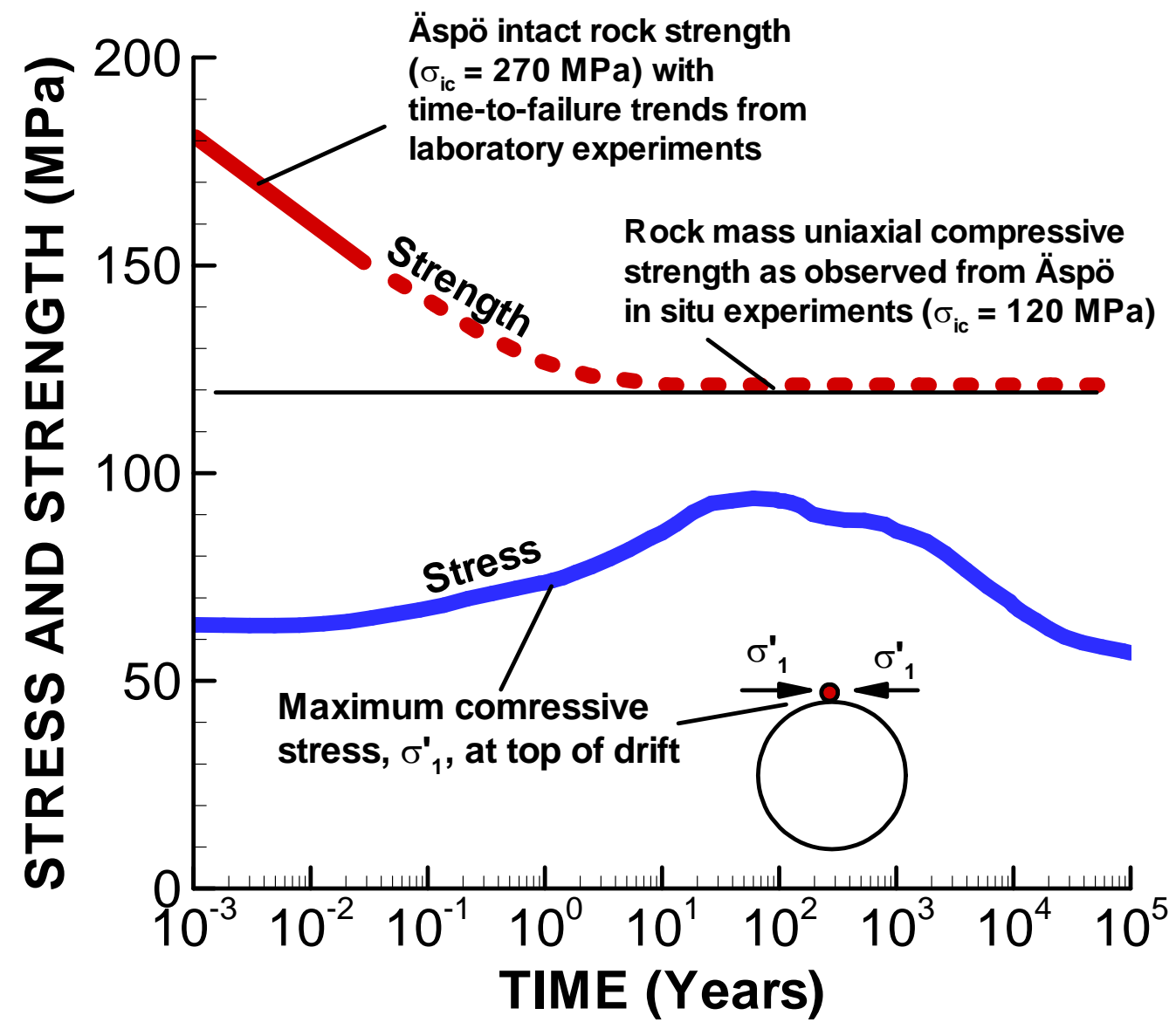

Figure 8. Schematic of time-dependent strength degradation and the evolution of maximum principal stress at the top of the emplacement drift in this simulation problem. The short-term strength was assumed to be $270 \mathrm{MPa}$; it has already dropped to $180 \mathrm{MPa}$ at $10^{-3}$ years (8 hours) 